\title{
PERSEPSI MASYARAKAT TERHADAP PERKEMBANGAN INDUSTRI MEUBEL DI DESA LEILEM KECAMATAN SONDER KABUPATEN MINAHASA
}

\author{
Claudia Mega Pajow \\ Oktavianus Porajouw \\ Ellen Grace Tangkere
}

\begin{abstract}
This study aims to analyze people's perceptions of the development of the furniture industry in Leilem Village, Sonder District. Community perception is very important to be able to foster active communication so that the development of the furniture industry in the village of Leilem continues to experience an increase in the type of furniture and its quality. This study uses primary data obtained through direct interviews with 30 respondents using a questionnaire to the community of Leilem Village, Sonder District using a simple random sampling method. The analysis used in this study was to use a Likert Scale analysis. The results showed that the index of public perception of the development of the furniture industry was at a point of $95.1 \%$ so it was classified as high. The development of the furniture industry is very influential for the survival of the community. A good industry is an opportunity for people to depend their lives on the results of the furniture industry. ${ }^{*}$ eprm ${ }^{*}$
\end{abstract}

Keywords: community perception, furniture industry, Leilem Village

\begin{abstract}
ABSTRAK
Penelitian ini bertujuan untuk menganalisis persepsi masyarakat terhadap perkembangan industri meubel di Desa Leilem Kecamatan Sonder. Persepsi masyarakat sangat penting untuk dapat menumbuhkan komunikasi aktif sehingga perkembangan industri meubel di Desa Leilem terus mengalami peningkatan jenis meubel maupun kualitasnya. Penelitian ini menggunakan data primer yang di peroleh melalui wawancara secara langsung pada 30 responden dengan menggunakan kuesioner kepada masyarakat Desa Leilem Kecamatan Sonder dengan menggunakan metode pengambilan sampel acak sederhana (simple random sampling), Analisis yang di gunakan dalam penelitian ini yaitu dengan menggunakan analisis Skala Likert. Hasil penelitian menunjukkan bahwa indeks persepsi masyarakat terhadap perkembangan industri meubel berada pada titik 95,1\% sehingga tergolong tinggi. Perkembangan industri meubel sangat berpengaruh bagi kelangsungan hidup masyarakat. Industri yang baik menjadi peluang bagi masyarakat untuk menggantungkan hidup mereka pada hasil-hasil industri meubel. ${ }^{* e p r m *}$
\end{abstract}

Kata kunci: persepsi masyarakat, industri meubel, Desa Leilem 


\section{PENDAHULUAN}

\section{Latar Belakang}

Sektor industri merupakan salah satu sektor utama sebagai penggerak ekonomi nasional, dimana sektor industri salah satu sektor prioritas pembangunan ekonomi, dengan tetap memperhatikan sektor lain. Dalam era globalisasi bangsa Indonesia dituntut untuk maju mengejar ketinggalan disemua sektor. Dengan memperbaiki disemua sektor melihat potensi-potensi yang ada akan memajukan Indonesia lebih berkembang dan bersaing dengan negara lain. Perkembangan sektor industri tidak terlepas dari perkembangan industri kecil. Peranan industri kecil sangat penting sehingga perlu upaya yang tepat untuk memacu pertumbuhan ekonomi daerah serta membuka lapangan kerja sebagai penopang perekonomian rakyat. Kemajuan sektor industri merupakan salah satu pemicu menuju kestabilan perekonomian. (Andiani, 2006).

Perkembangan sektor industri tidak terlepas dari perkembangan industri kecil. Peranan industri kecil sangat penting sehingga perlu upaya yang tepat untuk memacu pertumbuhan ekonomi daerah serta membuka lapangan kerja sebagai penopang perekonomian rakyat. Kemajuan sektor industri merupakan salah satu pemicu menuju kestabilan perekonomian. Kegiatan industri meubel yang timbul ini bercorak usaha kecil, industri menengah, industri besar, merupakan kegiatan yang berperan sebagai sistem ekonomi. peranan industri di Indonesia dicatat mampu meningatkan pendapatan dan diukur dari kesempatan kerja mampu menyerap tenaga kerja. Salah satunya industri mebel skala rumah tangga sampai dengan perseroan komanditer (CV). Industri mebel memiliki potensi yang cukup besar untuk tumbuh dan berkembang harus ditunjang dengan perajin yang terampil dan bahan baku yang melimpah.

Bagi produsen tidaklah mudah untuk mempertahankan dan mencari konsumennya, sehingga produsen harus terus mengembangkan bisnisnya seperti, membentuk sebuah citra yang baik untuk toko dan produknya, kepercayaan, kualitas pelayanan yang baik, serta kepuasan pelanggannya. Desa Leilem merupakan salah satu daerah Industri di Minahasa yang terus mengembangkan kwalitas produk hingga sekarang. memprodksi meubel merupakan aktifitas yang di warisan oleh masyarakat terdahulu secara turun temurun kepada anak-anak mereka sehingga keterampilan mereka tetap lestari. Masyarakat Desindustri meubel di Desa Leilem terus berkembang dan mengalami peningkatan pemesanan produk meubel.

Desa Leilem merupakan salah satu daerah Industri di Minahasa yang terus mengembangkan kwalitas produk hingga sekarang. memprodksi meubel merupakan aktifitas yang di warisan oleh masyarakat terdahulu secara turun temurun kepada anak-anak mereka sehingga keterampilan mereka tetap lestari. Masyarakat Desindustri meubel di Desa Leilem terus berkembang dan mengalami peningkatan pemesanan produk meubel.

Perkembangan industri meubel di Desa Leilem Kecamata Leilem juga terus menciptakan keunikan baru yang terus mengikuti kebutuhan konsumen sehigga kecamatan Sonder telah mempengaruhi perkembangan wilayah Kecamatan Sonder dalam memajukan perekonomian menjadi wilayah yang memiliki sektor industri yang dapat bersaing dan memberikan kontribusi cukup besar terhadap pendapatan masyarakat maupun daerah. Industri mebel di Desa Leilem dalam perkembangan awal berdirinya industri pada tahun 1930-1990 merupakan industri yang berorientasi atau menitik beratkan pada ketersedian bahan baku kayu yang dapat diperoleh dari kawasan sekitar Desa Leilem.

Pengolahan industri meubel sudah ada dari tahun 1930 di mulai dari pembuatan gerobak di mulai pada tahun 1960 pengrajin melihat peluang dan melakukan perkembangan produk. pengusaha mulai memproduksi furniture, seiring waktu meubel di Desa Leilem mulai di terima oleh masyarakat bahkan di ekspor hingga ke luar negri karena memiliki kwalitas yang baik.

Data penduduk dan Luas lahan di Desa Leilem Kecamatan Sonder jumlah keluarga sebanyak $1163 \mathrm{KK}$ dan jumlah keseluruhan luas lahan pemukiman $677 \mathrm{Ha}$. yang terbagi atas Desa Leilem Satu, 275 Ha, Desa Leilem Dua 197 
Ha, dan Leilem Tiga 205 Ha. Kegiatan memproduksi meubel telah di lakukan sejak lama dan di wariskan secara turun temurun oleh masyarakat. Desa Leilem dikenal dengan desa kawasan industri pertukangan kayu yang menghasilkan bermacam-macam mebel untuk rumah, tempat ibadah, hotel mulai dari produk unggulan Desa Leilem, lemari gantung untuk dapur kitchen set, meja kantor, meja biro, selain meubel masyarakat desa juga memproduksi gerobak sapi, kas truck, plafond, pintu, jendela, pondok atau gazebo. Dengan munggunakan bahan kayu yang di pilih oleh konsumen Block bort tripleks lapis kayu, dan kayu jenis unggulan kayu linggua, kayu cempaka dan kayu merah.

Perkembangan industri meubel di Desa Leilem di lihat dengan banyaknya permintaan pembuatan meubel dengan produk-produk unggul desa seperti kitchen set, lemari, tempat tidur terus berkembang dengan inovasi-inovasi baru. Berdasarkan data pra-survei Desa Leilem yang terdiri dari Leilem Satu, Leilem Dua, dan Leilem tiga mempunyai 39 usaha industri mebel dengan 6 usaha industri berbentuk Commanditaire Vennootschap (CV). Sebagian besar masyarakat berprofesi sebagai tukang kayu, kegiatan pembuatan industri mebel dikelola oleh masing-masing kepala keluarga di depan rumah dengan membuat bengkel-bengkel tempat pekerjaan.

\section{Konsep Persepsi}

Persepsi dari bahasa Latin perceptio, percipio adalah tindakan menyusun, mengenali, dan menafsirkan informasi guna memberikan gambaran dan pemahaman tentang lingkungan. Persepsi meliputi semua sinyal dalam sistem saraf, yang merupakan hasil dari stimulasi fisik dari organ pengindra. Seperti misalnya penglihatan yang merupakan cahaya yang mengenai retina pada mata, pencium yang memakai aroma dan pendengaran yang melibatkan gelombang suara. Persepsi dibentuk oleh pembelajaran, ingatan, harapan, dan perhatian. Persepsi sesungguhnya memerlukan proses belajar dan pengalaman dari hasil proses belajar dan interaksi seseorang akan memberikan pengalaman bagi dirinya untuk dapat membandingkan keadaan yang dihadapi. persepsi adalah proses menerima, membedakan, dan memberi arti terhadap stimulus yang diterima alat indra, sehingga dapat memberi kesimpulan dan menafsirkan terhadap objek tertentu yang diamatinya (Asrori, 2009).

Pengertian persepsi adalah proses yang berkaitan dengan masuknya pesan atau informasi kedalam otak manusia, melalui persepsi manusia terus menerus mengadakan hubungan dengan lingkungannya. Hubungan ini dilakukan lewat inderanya, yaitu indera pengelihat, pendengar, peraba, perasa, dan pencium (Slameto, 2010).

\section{Rumusan Masalah}

Berdasarkan uraian latar belakang dapat dirumuskan permasalahan sebagai berikut: Bagaimanakah persepsi masyarakat Desa Leilem terhadap perkembangan industri meubel.

\section{Tujuan}

Tujuan penelitian adalah: Untuk mengetahui persepsi masyarakat Desa Leilem Kecamatan Sonder terhadap perkembangan industri meubel.

\section{Manfaat Penelitian}

Penelitian ini bermanfaat untuk:

1. Menambah wawasan bagi pemerintah dan pihak terkait di Desa Leilem untuk lebih meningkatan pengembangan industri meubel.

2. Bagi pihak lain, dapat digunakan sebagai bahan acuan atau referensi untuk penelitian lebih lanjut sesuai kebutuhan yang diperlukan.

\section{METODE PENELITIAN}

\section{Waktu dan Tempat Penelitian}

Penelitian ini dilaksanakan di Desa Leilem, Kecamatan Sonder, Kabupaten Minahasa, selama 3 bulan mulai dari bulan Juli 2019 sampai bulan September 2019 di mulai dari persiapan, pengambilan data sampai pada penyusunan laporan hasil penelitian. 


\section{Teknik Pengumpulan Data}

Teknik pengumpulan data yang dilakukan dalam penelitian ini sebagai berikut:

a. Wawancara untuk data primer, yaitu teknik pengumpulan data dengan menggunakan Kuesioner yaitu suatu teknik dalam pengumpulan data dengan cara menggunakan daftar pertanyaan kepada setiap responden terpilih dengan melakukan dialog langsung antara peneliti dengan responden. Responden dalam penelitian ini adalah Masyarakat Desa Leilem Kecamatan Sonder. Daftar pertanyaaan yang di ajukan kepada responden di susun dengan alternatife jawaban yang sesuai dengan pendapat, pengetahuan, dan pandangan dari responden.

b. Studi kepustakaan untuk data sekunder, yaitu pengumpulan data dan bahan penelitian yang di peroleh dari kantor Desa Leilem Kecamatan Sonder. serta diperoleh dari internet, buku, jurnal, dan sumber lainnya yang berkaitan dengan masalah yang di bahas dalam penelitian ini.

\section{Konsep Pengukuran Variabel}

Konsep Pengukuran Variabel Variabelvariabel yang dikaji dalam penelitian ini adalah karakteristik responden, mencakup:

1)Jenis kelamin

2)Umur

3)Tingkat pendidikan, diukur menurut tingkatan pendidikan yang sudah ditamatkan yaitu SD, SMP, SMA, perguruan tinggi

4)Pekerjaan, yaitu pekerjaan yang dijalani oleh responden variabel yang di teliti persepsi masyarakat terhadap perkembangan industri meubel, yang diukur adalah:

1. Persepsi masyarakat, pendapat atau tanggapan yang di berikan masyarakat terhadap perkembangan industri meubel.

a. Industri meubel telah meningkatkan taraf hidup masyarakat.

b. Industri meubel terus berinovasi mengikuti kebutuhan masyarakat.

c. Pengusaha industri meubel menanggapi saran dan usul dari masyarakat.

2. Pengetahuan, masyarakat dan pengusaha terhadap industri meubel.

a. Pengusaha industri tahu memilih kayu dan bahan baku yang baik. b. Pelatihan kepada pengusaha dan masyarakat dalam memproduksi meubel.

c. Pengusaha industri yang terampil dalam memproduksi meubel.

3. Sikap, masyarakat mengembangkan industri meubel.

a. Mengembangkan usaha lewat promosi baliho dan media internet.

b. Hubungan yang baik antara pengusaha industri, dan masyarakat.

Untuk mengukur persepsi masyarakat telah disusun 8 pertanyaan dengan total responden 30 orang. Setiap jawaban dihubungkan dengan bentuk pernyataan.

\section{Metode Analisis Data}

Dalam penelitian ini analisis data yang digunakan adalah analisis data secara deskriptif dengan menggunakan skala Likert. Setelah itu disusun pertanyaan dan diberikan kepada responden. Jawaban setiap instrumen menggunakan skala Likert. Dengan cara perhitungan skor masing - masing pernyataan. Jumlah skor setiap kriterium = capaian skor $\mathrm{X}$ jumlah responden. Skala likert (likert scale) digunakan utuk mengukur sikap, pendapat, dan persepsi seseorang atau kelompok orang tentang fenomena seseorang (Sugiyono, 2002). Dalam Skala Likert, maka variabel yang di ukur dijabarkan menjadi indikator variabel. Kemudian indikator tersebut dijadikan sebagai titik tolak untuk menyusun item-item instrument yang dapat berupa pernyataan - pernyataan.

\section{HASIL DAN PEMBAHASAN}

\section{Gambaran Umum Wilayah Penelitian}

Desa Leilem adalah sebuah Desa di Kecamatan Sonder di Kabupaten Minahasa Sulawesi Utara Indonesia. Desa Leilem merupakan kawasan industri pertukangan kayu yang menghasilkan bermacam-macam meubel untuk Rumah, Kantor, dan Tempat Ibadah. Menjadikan kawasan produk unggul industri meubel yang dapat meningkatkan industri daerah dan kesejahteraan masyarakt. Desa Leilem merupakan hasil pemekaran yang terbagi atas Desa Leilem Satu dengan luas pemukiman 275 ha, Desa Leilem Dua 197 ha, dan Desa Leilem Tiga 205 ha. Desa Leilem berbatasan dengan: 
- Sebelah Utara: Desa Lahendong Kecamatan Tomohon Selatan

- Sebelah Timur: Desa Leilem Dua Kecamatan Sonder

- Sebelah Selatan: Desa Leilem Tiga Kecamatan Sonder

- Sebelah Barat: Kolongan atas Kecamatan Sonder.

Jumlah keluarga Desa Leilem Kecamatan Sonder sebanyak 1163 KK yang terbagi atas Deaa Leilem Satu 463 kk. Desa Leilem Dua 355 kk. Desa Leilem tiga 345 kk.

\section{Karakteristik Responden}

Karakteristik responden dalam penelitian ini diperoleh berdasarkan hasil survey dan wawancara langsung dengan masyarakat Desa Leilem Kecamatan Sonder. Karakteristik umum terdiri dari jenis kelamin, tingkat pendidikan, umur dan pekerjaan dari responden.

\section{Karakteristik Responden Menurut Tingkat Umur}

Tingkat umur bervariasi mulai dari responden yang berumur 21 tahun sampai 51 tahun ke atas. Hal ini di karenakan tidak di tentukan mengenai tingkat umur dalam penentuan responden. Pengelompokan umur responden di lakukan dalam upaya mempermudah proses pengolahan data. Kelompok umur di bagi menjadi IV kelompok yaitu 21-30 tahun, 31-40 tahun, 41-50 tahun, dan 51 tahun ke atas.

Tabel 1. Jumlah dan Persentase Responden menurut Tingkat Umur

\begin{tabular}{cccc}
\hline No. & Umur & $\begin{array}{c}\text { Jumlah } \\
\text { Responden }\end{array}$ & Persentase (\%) \\
\hline 1. & $21-30$ & 7 & 23,33 \\
2. & $31-40$ & 6 & 20,00 \\
3. & $41-50$ & 11 & 36,67 \\
4. & $>51$ & 6 & 20,00 \\
\hline \multicolumn{2}{c}{ Jumlah } & $\mathbf{3 0}$ & $\mathbf{1 0 0 , 0 0}$ \\
\hline
\end{tabular}

Sumber data primer, 2019

Tabel 1 menunjukkan bahwa umur responden yaitu dari 21 tahun sampai lebih dari 51 tahun. Umur responden pada interval 31-40 tahun dan lebih dari 51 tahun memiliki nilai persentase yang sama yaitu 20 persen masingmasing enam responden. pada interval umur 4150 tahun merupakan persentase nilai terbanyak dengan persentase 36.67 persen dengan responden sebanyak 11 orang, dan 23.33 persen merupakan persentase yang terbanyak kedua yaitu interval 21-30 tahun dengan jumlah responden 7 orang.

\section{Karakteristik Responden Menurut Tingkat Pendidikan}

Semakin tinggi tingkat pendidikan seseorang semakin banyak pula pengetahuan atau wawasan yang di miliki baik itu menciptakan, menerapkan teknologi baru serta inovasi-inovasi yang baru dari hasil penelitian yang di lakukan. Tingkat pendidikan responden yaitu SD, SMP, SMA, S1.

Tabel 2. Jumlah dan Persentase Responden menurut Tingkat Pendidikan

\begin{tabular}{cccc}
\hline No. & Pendidikan & $\begin{array}{c}\text { Jumlah } \\
\text { Responden }\end{array}$ & $\begin{array}{c}\text { Persentase } \\
(\boldsymbol{\%})\end{array}$ \\
\hline 1. & SD & 2 & 6,67 \\
2. & SMP & 3 & 10,00 \\
3. & SMA & 18 & 60,00 \\
4. & S1 & 7 & 23,33 \\
\hline & Jumlah & $\mathbf{3 0}$ & $\mathbf{1 0 0 , 0 0}$ \\
\hline
\end{tabular}

Sumber data primer, 2019

Tabel 2 menunjukkan bahwa perolehan persentase dari masing-masing tingkat pendidikan yaitu, dengan persentase terbanyak SMA 60 persen dengan jumlah responden 18 orang. dan persentase responden yang terkecil SD 6, 67 persen dengan jumlah responden 2 orang. Jumlah persentase pada tingkat pendidikan S1 yaitu 23.33 persen dengan jumlah responden 7 orang, dan SMP dengan peresentase 10 persen dengan jumlah responden 3 orang.

\section{Karakteristik Responden Menurut Pekerjaan}

Jenis pekerjaan sangat mempengaruhi kesejahteraan dan cara masyarakat untuk bertahan hidup. Masing-masing masyarakat memiliki pekerjaan yang berbeda-beda untuk memenuhi kebutuhan keluarga sehati-hari. 
Tabel 3. Jumlah dan Persentase Responden menurut Pekerjaan

\begin{tabular}{cccc}
\hline No. & Pendidikan & $\begin{array}{c}\text { Jumlah } \\
\text { Responden }\end{array}$ & $\begin{array}{c}\text { Persentase } \\
(\boldsymbol{\%})\end{array}$ \\
\hline 1. & PNS & 4 & 13,13 \\
2. & Perangkat & 2 & 6,67 \\
& Desa & & \\
3. & Petani & 3 & 10,00 \\
4. & IRT & 5 & 16,67 \\
5. & Swasta & 2 & 6,67 \\
6. & Wiraswasta & 14 & 46,66 \\
\hline & Jumlah & $\mathbf{3 0}$ & $\mathbf{1 0 0 , 0 0}$ \\
\hline
\end{tabular}

Sumber data primer, 2019

Tabel 3 menunjukkan bahwa dalam penelitian ini terdapat 6 kategori jenis pekerjaan dari responden yaitu, PNS, Perangkat Desa, Petani, IRT, Swasta, dan Wira Swasta. Kategori Wira Sasta merupakan jenis pekerjaan terbanyak karena sebagian besar masyrakat memiliki usaha sendiri yaitu memproduksi meubel dengan persentase 46.6 persen dengan jumlah responden 14 orang. Jenis pekerjaan pegawai negeri sipil jumlah persentase 13.33 dengan jumlah responden 4 orang. Jenis pekerjaan petani jumlah persentase 10 persen dengan jumlah responden 3 orang. Jenis pekerjaan ibu rumah tangga dengan persentase 16.66 persen dengan jumlah responden 5 orang. Sedangkan jenis pekerjaan yang paling sedikit perangkat desa, swasta masing-masing 2 responden.

\section{Karakteristik Responden Berdasarkan Jenis Kelamin}

Tabel 4 menunjukkan bahwa jumlah responden jenis jenis kelamin laki-laki lebih banyak yaitu 63.33 persen dengan jumlah responden 19 orang. dan jumlah responden perempuan lebih sedikit yaitu 11 orang dengan persentase 36.67 persen.

Tabel 4. Jumlah dan Persentase Responden menurut Jenis Kelamin

\begin{tabular}{cccc}
\hline No. & Pendidikan & $\begin{array}{c}\text { Jumlah } \\
\text { Responden }\end{array}$ & Persentase (\%) \\
\hline 1. & Perempuan & 19 & 63,33 \\
2. & Laki-Laki & 11 & 36,67 \\
\hline & Jumlah & $\mathbf{3 0}$ & $\mathbf{1 0 0 , 0 0}$ \\
\hline
\end{tabular}

Sumber data primer, 2019

\section{Persepsi Masyarakat}

\section{Persepsi Masyarakat Terhadap Peningkatan Taraf Hidup}

Masyarakat Desa Leilem sangat mengharapkan untuk kedepannya agar supaya industri meubel lebih baik lagi di bandingkan dengan tahun-tahun sebelumnya. dengan berkembangnya industri meubel di Desa Leilem dapat meningkatkan taraf hidup masyarakat desa serta meningkatkan kesejahteraan masyarakat dengan membuka lapangan pekerjaan bagi masyarakat sehingga mengurangi pengangguran di masyarakat.

Tabel 5. Persepsi Masyarakat Terhadap Peningkatan Taraf

\begin{tabular}{cccccc}
\multicolumn{7}{c}{ Hidup } & & & \\
\hline No. & Kriteria & Skor & Responden & $\begin{array}{c}\text { Total } \\
\text { Skor }\end{array}$ & $\begin{array}{c}\text { Persentase } \\
(\%)\end{array}$ \\
\hline 1. & Setuju & 3 & 26 & 78 & 90,66 \\
2. & $\begin{array}{c}\text { Ragu- } \\
\text { ragu }\end{array}$ & 2 & 4 & 8 & 9,34 \\
$3 . \quad$ & Tidak & 1 & - & - & - \\
\hline & Tahu & & & & \\
\hline \multicolumn{2}{c}{ Jumlah } & & $\mathbf{3 0}$ & $\mathbf{8 6}$ & $\mathbf{1 0 0 , 0 0}$
\end{tabular}

Sumber data primer, 2019

Tabel 5 menunjukkan bahwa 90.66 persen responden setuju dengan pernyataan industri meubel telah meningkatkan taraf hidup masyarakat. Sedangkan sebanyak 9.34 persen masih ragu-ragu dalam pernyataan tersebut total skor yang di peroleh dari 30 responden pada indikator pernyataan nomor satu ini adalah 86 . Angka indeks persepsi masyarakat mengenai pernyataan satu yaitu: $86 / 90 \times 100 \%=95.56 \%$ sehingga nilainya tergolong tinggi karena masyarakat Desa Leilem banyak berpendapat setuju terhadap pernyataan industri meubel telah meningkatkan taraf hidup masyarakat.

\section{Persepsi Masyarakat Terhadap Perkembangan Inovasi Baru Sesuai Kebutuhan Masyarakat}

Inovasi baru sangat di butuhkan oleh pengusaha industri meubel yaitu harus lebih kreatif dalam menciptakan ide-ide model baru yang di minati masyarakat sehingga masyarakat merasa puas dengan hasil industri meubel. Persepsi dari masyarakat terhadap industri meubel terus berinovasi mengikuti kebutuhan konsumen dapat di lihat pada Tabel 6. 
Tabel 6. Persepsi Masyarakat Terhadap Perkembangan Inovasi Baru Sesuai Kebutuhan Masyarakat

\begin{tabular}{cccccc}
\hline No. & Kriteria & Skor & Responden & $\begin{array}{c}\text { Total } \\
\text { Skor }\end{array}$ & $\begin{array}{c}\text { Persentase } \\
(\mathbf{\%})\end{array}$ \\
\hline 1. & Setuju & 3 & 28 & 84 & 95,46 \\
2. & $\begin{array}{c}\text { Ragu- } \\
\text { ragu }\end{array}$ & 2 & 2 & 4 & 4,55 \\
3. & $\begin{array}{c}\text { Tidak } \\
\text { Tahu }\end{array}$ & 1 & - & - & - \\
\hline & Jumlah & & & \\
\hline & & & & $\mathbf{8 8}$ & $\mathbf{1 0 0 , 0 0}$ \\
\hline
\end{tabular}

Tabel 6 menunjukkan bahwa 95.46 persen setuju dengan pernyataan industri meubel terus berinovasi mengikuti kebutuhan konsumen. Sedangkan sebanyak 4.55 persen masih ragu-ragu dalam pernyataan tersebut. Total skor yang di peroleh dari 30 responden pada indikator pernyataan nomor dua ini adalah sebesar 88. Angka indeks persepsi masyarakat mengenai pernyataan dua yaitu: $88 / 90 \times 100 \%=97.78 \%$. sehingga nilainya tergolong tinggi karena dalam perkembangan Industri meubel di Desa Leilem terus berinovasi mengikuti kebutuhan masyarakat.

\section{Persepsi Masyarakat Terhadap Pengusaha Industri Menanggapi Saran Dan Usul Dari Masyarakat \\ Dalam perkembangan suatu usaha saran} dan usul dari masyarakat merupakan hal yang sangat penting dalam menunjang keberhasilan usaha. Masyarakat dan konsumen dapat memberikan saran dan usul yaitu respon dan kritik bagi pengusaha meubel untuk kemajuan industri meubel yang lebih baik dan berkembang. Hal ini dapat di lihat pada Tabel 7.

Tabel 7. Persepsi Masyarakat Terhadap Pengusaha Industri Menanggapi Saran Dan Usul Dari Masyarakat

\begin{tabular}{cccccc}
\multicolumn{6}{c}{ Menanggapi Saran Dan Usul Dari Masyarakat } \\
\hline No. & Kriteria & Skor & Responden & $\begin{array}{c}\text { Total } \\
\text { Skor }\end{array}$ & $\begin{array}{c}\text { Persentase } \\
(\mathbf{\%})\end{array}$ \\
\hline 1. & Setuju & 3 & 29 & 87 & 97,78 \\
2. & $\begin{array}{c}\text { Ragu- } \\
\text { ragu }\end{array}$ & 2 & 1 & 2 & 2,22 \\
& & & & - \\
3. & Tidak & 1 & - & - & \\
\hline & Tahu & & & & $\mathbf{8 9}$ \\
\hline & Jumlah & $\mathbf{3 0}$ & &
\end{tabular}

Tabel 7 menunjukkan bahwa 97.78 setuju dengan pernyataan. Sedangkan sisanya sebanyak $2.22 \%$ responden masih ragu-ragu dengan pernyataan tersebut. Total skor yang di peroleh dari 30 responden pada indikator pernyataan nomor 3 ini adalah sebesar 89. Angka indeks persepsi masyarakat mengenai pernyataan tiga yaitu: $89 / 90 \times 100 \%=$ $98,89 \%$, sehingga nilainya tergolong tinggi karena pengusaha industri dapat menanggapi saran dan usul dari masyarakat.

\section{Pengetahuan}

\section{Pengetahuan Masyarakat Terhadap Pengusaha Meubel Tahu Memilih Kayu Dan Bahan Baku Yang Baik}

Penyediaan bahan baku merupakan hal penting dalam menunjang hasil produksi meubel. yaitu pengusaha meubel harus menyediakan bahan baku sebelum persediaan habis. Hal ini supaya pekerjaan proses pembuatan meubel tetap terlaksana tanpa terhambat karena kehabisan bahan baku. Hal ini dapat di lihat pada Tabel 8 .

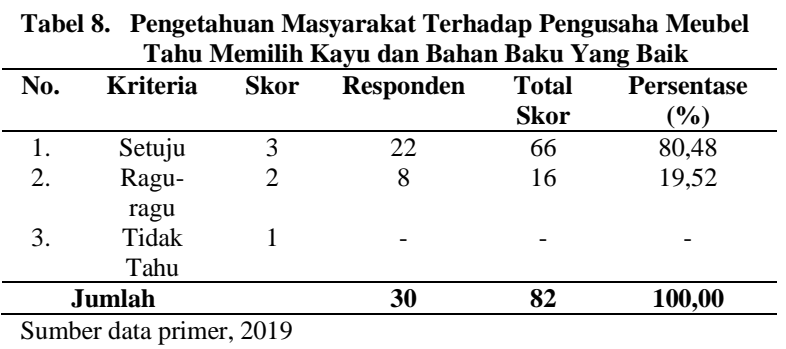

Tabel 8 menunjukkan bahwa $80.48 \%$ setuju dengan pernyataan. Sedangkan sisanya sebanyak $19.52 \%$ responden masih ragu-ragu dengan pernyataan tersebut. Total skor yang di peroleh dari 30 responden pada indikator pernyataan nomor 4 adalah sebesar 82. Angka indeks persepsi masyarakat mengenai pernyataan empat yaitu $82 / 90 \times 100 \%=$ $91.11 \%$. sehingga nilainya tergolong tinggi karena pengusaha industri tahu memilih kayu.

\section{Pengetahuan Pelatihan Kepada Masyarakat Dan Pengusaha Dalam Memproduksi Meubel}

Perkembangan industri meubel salah satu faktor penentu keberhasilannya adalah pengetahuan yang di milki untuk mengembangkannya. yaitu pengusaha industri meubel, Kelompok organisasi meubel, dan dari produk HPL TACO, memberikan pelatihan pada pembuatan tahap akhir High Pressure Laminate (HPL) bahan pelapis furniture altenatif terbuat dari resin, penilon, dan kraft paper. pelatihan di berikan kepada masyarakat terutama bagi mereka yang masih pemula untuk belajar memproduksi meubel.

Tabel 9. Pengetahuan Pelatihan Kepada Masyarakat dan Pengusaha dalam Memproduksi Meubel

\begin{tabular}{cccccc}
\hline No. & Kriteria & Skor & Responden & $\begin{array}{c}\text { Total } \\
\text { Skor }\end{array}$ & $\begin{array}{c}\text { Persentase } \\
(\mathbf{\%})\end{array}$ \\
\hline 1. & Setuju & 3 & 24 & 72 & 88,89 \\
2. & $\begin{array}{c}\text { Ragu- } \\
\text { ragu }\end{array}$ & 2 & 3 & 6 & 7,41 \\
3. & $\begin{array}{c}\text { Tidak } \\
\text { Tahu }\end{array}$ & 1 & 3 & 3 & 3,7 \\
\hline & Jumlah & $\mathbf{3 0}$ & $\mathbf{8 1}$ & $\mathbf{1 0 0 , 0 0}$ \\
\hline Sumber data primer, 2019 & & &
\end{tabular}


Tabel 9 menunjukkan bahwa 88.89 persen setuju dengan pernyataan. Sedangkan sisanya sebanyak 7.41 persen responden masih ragu-ragu dengan pernyataan tersebut. Responden yang berpendapat tidak tahu 3 yang dengan persentase 3.7 persen. Total skor yang di peroleh dari 30 responden pada indikator pernyataan nomor 5 adalah sebesar 81. Angka indeks persepsi masyarakat mengenai pernyataan 5 yaitu $81 / 90 \times 100 \%=90 \%$. Sehingga nilainya tergolong tinggi karena masyarakat setuju dengan pernyataan ini.

\section{Pengusaha Industri Terampil Dalam Mengembangkan Industri Meubel}

Hasil pembuatan meubel harus sesuai dengan keinginan konsumen dan masyarakat. pengusaha meubel di harapkan lebih teliti dalam memproduksi meubel mulai dari pemilihan bahan baku yang berkualitas baik, sampai pada proses pembuatan hingga proses akhir.

\begin{tabular}{|c|c|c|c|c|c|}
\hline No. & Kriteria & Skor & Responden & $\begin{array}{l}\text { Total } \\
\text { Skor }\end{array}$ & $\begin{array}{c}\text { Persentase } \\
(\%)\end{array}$ \\
\hline 1. & Setuju & 3 & 25 & 75 & 88,21 \\
\hline 2. & $\begin{array}{c}\text { Ragu- } \\
\text { ragu }\end{array}$ & 2 & 5 & 10 & 11,79 \\
\hline 3. & $\begin{array}{l}\text { Tidak } \\
\text { Tahu }\end{array}$ & 1 & - & - & - \\
\hline \multicolumn{2}{|c|}{ Jumlah } & & 30 & 85 & 100,00 \\
\hline
\end{tabular}

Tabel 10 menunjukkan bahwa 88.21 persen setuju dengan pernyataan. Sedangkan sisanya sebanyak 11.79 persen responden masih ragu-ragu dengan pernyataan tersebut. Total skor yang di peroleh dari 30 responden pada indikator pernyataan nomor enam adalah sebesar 85 . Angka indeks persepsi masyarakat mengenai pernykataan ini $85 / 90 \times 100 \%=94.44 \%$ sehingga nilainya tergolong tinggi karena pengusaha industri terampil dalam memproduksi meubel.

\section{Sikap}

\section{Sikap Masyarakat Mengembangkan Industri Meubel}

Pembuatan baliho di depan tempat usaha juga menjadi penunjang promosi meubel karena mudah di lihat oleh masyarakat. Selain itu agar perkembangan meubel di masyarakat terus tercipta perlu adanya hubungan yang baik antara pengusa industri dan masyarakat.

\section{Sikap Mengembangkan Meubel Melalui Promosi Baliho Dan Internet}

Promosi barang merupakan salah satu keberhasilan perkembangan suatu usaha. banyak konsumen mendapatkan informasi lewat media internet.

\begin{tabular}{|c|c|c|c|c|c|}
\hline No. & Kriteria & Skor & Responden & $\begin{array}{l}\text { Total } \\
\text { Skor }\end{array}$ & $\begin{array}{c}\text { Persentase } \\
(\%)\end{array}$ \\
\hline 1. & Setuju & 3 & 24 & 72 & 85,77 \\
\hline 2. & $\begin{array}{l}\text { Ragu- } \\
\text { ragu }\end{array}$ & 2 & 6 & 12 & 14,23 \\
\hline 3. & $\begin{array}{l}\text { Tidak } \\
\text { Tahu }\end{array}$ & 1 & - & - & - \\
\hline \multicolumn{2}{|c|}{ Jumlah } & & 30 & 84 & 100,00 \\
\hline
\end{tabular}

Tabel 11 menunjukkan bahwa $85.77 \%$ setuju dengan pernyataa sedangkan sisanya sebanyak $14.23 \%$ responden masih ragu-ragu dengan pernyataan tersebut total skor yang di peroleh dari 30 respnse pada indikator pernyataan nomor tujuh adalah sebesar 84. Angka indeks pernyataan $84 / 90 \times 100 \%=93.33 \%$ sehingga nilainya tergolong tinggi karena masyarakat Desa Leilem banyak berpendapat setuju terhadap pernyataan indikator nomor tujuh.

\begin{tabular}{cccccc}
\multicolumn{6}{l}{ Tabel 12. } \\
\multicolumn{6}{c}{ Hubungan Antara Pengusaha Industri, Konsumen dan } \\
Masyarakat
\end{tabular}

\begin{tabular}{cccc}
\hline Jumlah & $\mathbf{3 0}$ & $\mathbf{9 0}$ & $\mathbf{1 0 0 , 0 0}$ \\
\hline Sumber data primer, 2019 & & &
\end{tabular}

Tabel 12 menunjukkan bahwa 100\% masyarakat setuju dengan pernyataan indikator nomor delapan. Total skor yang di peroleh dari 39 responden adalah 90. Angka indikator $90 / 90 \times 100 \%=100$ Sehingga nilainya tergolong tinggi karena seluruh responden menjawab setuju dengan pernyataan hubungan yang baik antara pengusaha industri, konsumen, dan masyarakat.

\section{Persepsi Masyarakat Terhada Perkembangan Industri Meubel}

Untuk mengetahui letak persepsi masyarakat terhadap perkembangan industri meubel, maka perlu di hitung jumlah keseluruhan skor pada setiap kriterium, dimana 
sesuai hasil penelitian ini skor mencapai 685 (tinggi). Pada penelitian ini jumlah skor ideal (skor tertinggi) yaitu 720 dari jumlah skor terendah yaitu 240. Berdasarkan data dari sebanyak delapan instrumen pernyataan yang di ajukan kepada 30 responden maka di peroleh total skor 685 dengan letak indeks di tentukan berdasarkan skala likert berikut.

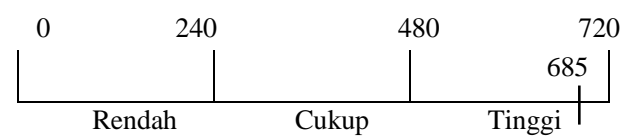

Secara persentase angka indeks persepsi masyarakat terhadap perkembangan industri meubel terletak pada

$$
\begin{aligned}
\text { Tingkat sikap } & =\frac{\text { Jumlah skor hasil pengumpulan data }}{\text { Jumlah skor ideal tertinggi }} \\
& =\frac{685}{720} \times 100 \%=95,1 \%
\end{aligned}
$$

Berdasarkan hasil analisis menggunakan skala likert, maka dapat di ketahui bahwa indeks persepsi masyarakat terhadap perkembangan industri meubel berada pada titik 95,1\% dan tergolong tinggi.

Perkembangan industri meubel sangat berpengaruh bagi kelangsungan hidup masyarakat. Industri yang baik menjadi peluang bagi masyarakat untuk menggantungkan hidup mereka pada hasilhasil industri meubel. Harapan masyarakat industri meubel dapat berkontribusi untuk perkembangan desa sehingga dapat membuka lapangan pekerjaan serta adanya inovasiinovasi baru serta produk yang lebih moderen sehingga perkembangan meubel semakin maju dan tingkat kesejahteraan masyarakat akan terus meningkat.

Berdasarkan hasil penelitian Masyarakat Desa Leilem mempunyai persepsi industri Meubel di Desa Leilem sangat baik dengan hasil penjualan yang sangat menguntungkan sehingga dapat membuka lapangan pekerjaan, sehingga hasil industri meubel dapat meningkatkan taraf hidup masyaraka Desa Leilem.

\section{KESIMPULAN DAN SARAN}

\section{Kesimpulan}

Berdasarkan hasil penelitian Persepsi Masyarakat Terhadap Perkembangan Industri Meubel di Desa Leilem Kecamatan Sonder yang di ukur ketiga komponen pendapat atau persepsi masyarakat, pengetahuan, dan sikap yaitu:

1. Pendapat atau persepsi masyarakat berada pada kategori Baik karena pembuatan industri meubel di Desa Leilem Kecamatan Sonder dapat membuka lapangan pekerjaan yang baru bagi masyrakat desa sehingga dapat meningkatkan taraf hidup masyarakat.

2. Pengetahuan berada pada kategori Baik karena tukang kayu memberikan pelatihan kepada masyarakat sesuai dengan pengetahuan dan keahlian yang mereka miliki. Selain itu Tukang kayu mendapat pelatihan dari produk TACO dengan harapan keahlian dari tukang kayu lebih berkembang sehingga dapat menciptakan inovasi baru dan pemesanan meubel akan terus meningkat.

3. Sikap berada pada kategori Baik karena masyarakat dan tukang kayu selalu menjaga kepercayaan kosumen dengan menjalin hubungan yang baik, serta mempromosikan meubel lewat media internet dan baliho sehinngga di harapkan dapat memudahkan konsumen untuk memesan meubel.

\section{Saran}

Bagi masyarakat desa leilem untuk tetap menjaga kepercayaan konsumen, dan tukang kayu untuk pemula agara dapat lebih banyak belajar tentang kayu dan bahan baku yang baik sehingga lebih terampil dalam memproduksi meubel.

\section{DAFTAR PUSTAKA}

Andiani, Indri. 2006. Analisis Struktur-PerilakuKinerja Industri Susu Di Indonesia [skripsi]. Departemen Ilmu Ekonomi Fakultas Ekonomi Dan Manajemen ITB, Bogor. 
Asrori, H. Mohammad. 2009. Penelitian Tindakan Kelas. Bandung: CV Wacana.

Slameto. 2010. Belajar dan Faktor yang Mempengaruhinya. Jakarta: Tineke Cipta.
Sugiyono. 2002. Metode Penelitian Administrasi. Bandung: Alfabeta. 